\title{
SUBPERIOSTEAL JUXTA-ARTICULAR OSTEOID OSTEOMA
}

\author{
KARL BRABANTS, STAF GEENS, B. VAN DAMME
}

From Lier Regional Hospital and the University Hospital Leuven, Belgium

\begin{abstract}
Subperiosteal osteoid osteoma in a juxta-articular site presents a diagnostic challenge. The clinical features of joint stiffness, synovitis, muscle atrophy and local warmth may suggest arthritis rather than osteoid osteoma, while radiographs, bone scans and angiograms may not be diagnostic. We describe four cases of this rare condition.
\end{abstract}

Although most orthopaedic surgeons are well aware of osteoid osteoma (Bleifeld 1981), the diagnosis of this small benign tumour is often delayed for months or even years (Jaffe 1958; Dinant and Desser 1981). Clinical symptoms may present long before radiographic change is evident: in unusual locations the lesion may remain radiographically invisible (Jaffe 1935). This applies especially to a nidus which is juxta-articular and subperiosteal (Davison 1956; Flaherty, Pugh and Dockerty 1956; Freiberger et al. 1959; Marcove and Freiberger 1966; Morton and Bartlett 1966; Shifrin and Reynolds 1971: Corbett et al. 1974: Sim. Dahlin and Beabout 1975; Micheli and Jupiter 1978; Swee, McLeod and Beabout 1979; Wiener and Kirschenbaum 1980; Apple and Loughlin 1981; Cronemeyer et al. 1981).

An osteoid osteoma in a periarticular site often presents as joint disease with stiffness, synovitis, muscle atrophy and local warmth, suggestive of hypertrophic monarticular arthritis (Sherman 1947a,b). Standard radiographs are often negative, and a zone of slight deossification (most often with no superimposed periosteal reaction) may be the only sign, even on tomograms. Chronic lesions may be associated with joint narrowing. A technetium- $99 \mathrm{~m}$ bone scan is often non-specific; there is a diffuse increase in isotope uptake instead of a typical hot spot. Angiograms, which are often helpful in localisation of osteoid osteoma in cortical or cancellous bone, are likely to reveal little when the osteoma is subperiosteal.

We report four patients with a diagnosis of subperiosteal juxta-articular osteoid osteoma, and in view of the rarity of the condition, we describe them in detail.

K. Brabants, MD. Orthopaedic Surgeon

S. Geens, MD. Orthopaedic Surgeon

Regional Hospital Lier. Mechelsestraat. Lier, Belgium.

B. van Damme. MD. Pathologist

University Hospital K.U.L.. Leuven. Belgium.

Requests for reprints should be sent to Dr K. Brabants. Hofstraat 6. 2500 Lier. Belgium.

(. 1986 British Editorial Society of Bone and Joint Surgery $0301620 \times 862043 \$ 2.00$
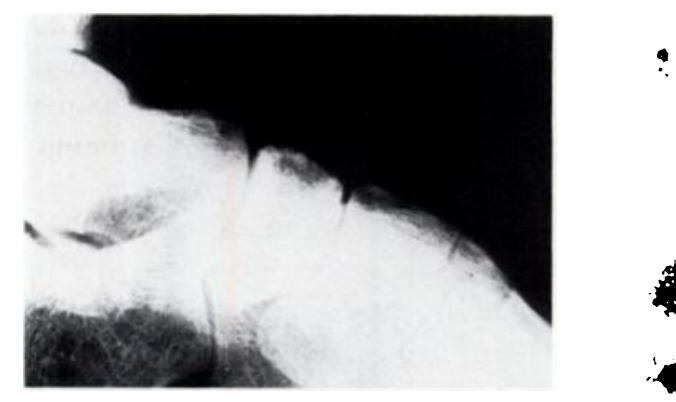

Fig. 1

Fig. 2 -

Case 1. Figure 1-Radiographs of the left foot showing only a slight superficial erosion in a juxta-articular position on the neck of the talus. Figure 2-Bone scan of the feet. From above down: anterior. left lateral and right lateral views. There is diffuse increase in activity without a definite hot spot. Figure 3-Angiogram showing a small curled artery on the neck of the talus.
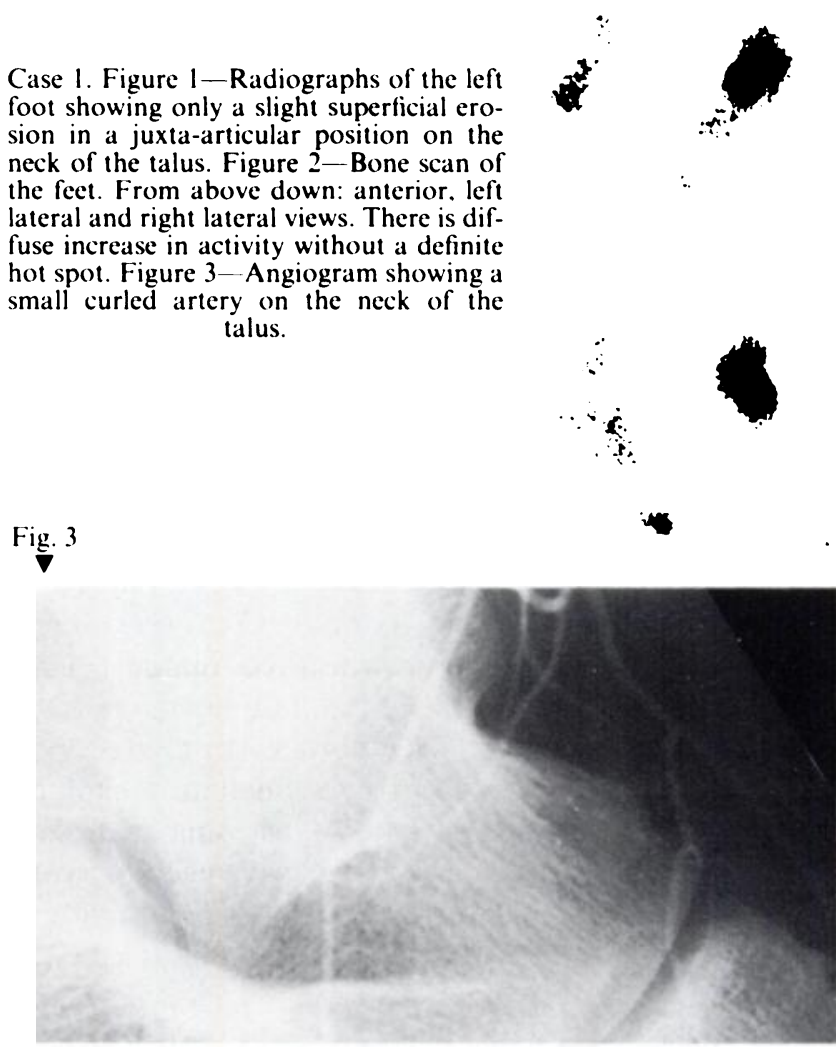


\section{CASE HISTORIES}

Case 1. A 30-year-old salesman gave a one-year history of pain on the medial side of the left ankle and talus, which was present at rest, even at night. The pain increased on standing and walking, causing a definite limp, and was relieved by salicylates. Swelling in the evenings obliged the patient to loosen his shoelaces. On examination there was local tenderness on the medial aspect of the talus over a small swollen area which was warm. Movement of the foot was painful and restricted.

Radiographs (Fig. 1), including tomograms, showed no convincing signs, and a technetium- $99 \mathrm{~m}$ bone scan showed only a diffuse increase in uptake at the ankle and hindfoot, maximal at the neck of the talus (Fig. 2). Angiography revealed an abnormally curled arterial branch of the dorsalis pedis artery near the lesion (Fig. 3 ). There was no hypervascularity or localised blush such as has been described in other types of osteoid osteoma (Swee et al. 1979).
After a few months he was taking salicylates to relieve his night pain. Severe elbow stiffness and muscle atrophy suggested a diagnosis of monarticular arthritis. Radiographs and tomograms were normal but a bone scan showed diffuse increase in uptake at the elbow which was maximal in the lower humerus lateral to the olecranon process. Anti-inflammatory drugs, local physiotherapy and night splints failed to prevent increasing symptoms.

Eventually, the region of maximal tenderness was explored and a bone biopsy taken. Histology showed an alteration in trabecular pattern but no nidus. Symptoms persisted and required two to three grams of salicylates daily for relief.

We first saw this patient two and a half years after the onset of pain. His elbow was partly ankylosed with only 20 of flexion and extension, though forearm rotation was preserved. There was marked muscle atrophy with tenderness over the dorsilateral humerus close to the olecranon. Radiographic change was minor and subtle (Fig. 4). A bone scan showed diffuse increase

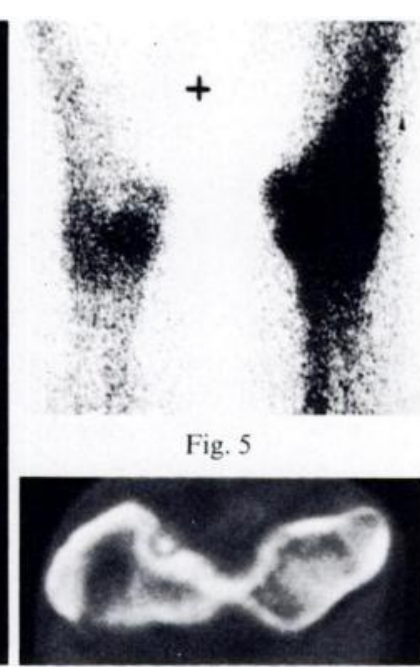

Fig. 6

Case 2. Figure 4-Radiograph showing a possible small zone of deossification on the radial side of the distal humerus. Figure 5-Bone scan showing diffuse increase in activity and a local hot spot. Figure 6-The subperiosteal nidus well demonstrated by a CT scan of the distal humerus.

The tender area was explored 15 months after the onset of symptoms. The synovium of the talonavicular joint was hypertrophic, and at its margin on the neck of the talus there was a brownish-red tumour. This resembled a small mass of granulation tissue and the underlying bone was soft. The tumour was excised with its surrounding bone and nearby synovium. Histology showed a typical nidus of osteoid osteoma with surrounding reactive synovitis. The pain was relieved except for slight symptoms of post-traumatic arthritis, and the patient returned to work three months after operation.

Case 2. A 22-year-old medical student developed pain in the right elbow which was made worse by playing tennis. in uptake, most pronounced in the area of clinical tenderness (Fig. 5); a CT scan demonstrated a typical nidus (Fig. 6).

The tender zone was explored under brachial plexus anaesthesia and a pneumatic tourniquet. A reddishbrown mass of granulation tissue, $0.5 \mathrm{~cm}$ in diameter, was seen through the overlying periosteum. This mass was very tender to touch although the surrounding tissues were completely anaesthetic. The lesion was excised and shown histologically to be a typical nidus of osteoid osteoma. Pain was completely relieved by the operation and full elbow movement was eventually regained. 
Case 3. A 26-year-old factory worker had developed pain in the right foot after a trivial ankle sprain one year previously. Treatment with local steroids and immobilisation had been unsuccessful and his night pain was relieved only by indomethacin.

Radiographs were normal. The use of arch supports for a year did not help. A bone scan two years after onset showed increased uptake at the neck of the talus (Fig. 7). The area of maximal local tenderness was explored and a small area of granulation tissue was removed from the dorsum of the neck of the talus. Sections showed a typical osteoid osteoma (Fig. 8) with concomitant synovitis of the neighbouring joint. The synovium of both the talonavicular and the ankle joint was inflamed and hypertrophic. There was complete relief of pain after operation and the patient returned to work two months later.

\section{DISCUSSION}

Osteoid osteoma was distinguished from chronic inflammatory lesions and recognised as a benign bone tumour by Jaffe in 1935, and in 1958 he wrote "An osteoid osteoma is a small but painful bone lesion, and it is its small size and consistent painfulness that strikingly characterise it clinically. It often gives rise to pain before its presence is even demonstrable on X-ray pictures ... Fortunately, most patients learn quickly that an adequate dose of aspirin almost invariably relieves the pain ... While the lesion may appear in almost any bone, the tibia and femur are by far the most common localisations for it ... The roentgenographic picture constitutes the most valuable diagnostic guide to the lesion; the nidus appears as a relatively radiolucent focus in the affected part of the bone. It is usually, though not always, surrounded by a

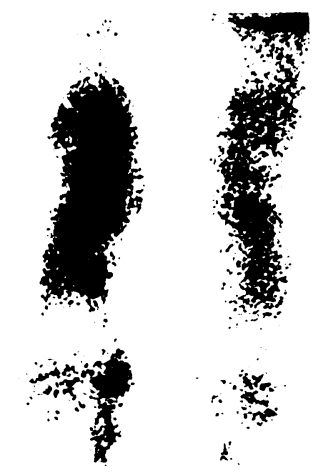

Fig. 7
Case 3. Figure 7-A bone scan of the feet and ankles showing an area of increased uptake on the right corresponding to the zone of maximal tenderness on the neck of the talus. Figure 8 Low-power view of the lesion. A narrow margin of widened bone trabeculae surrounds a typical nidus (haematoxylin and cosin. $\times 80$ ).

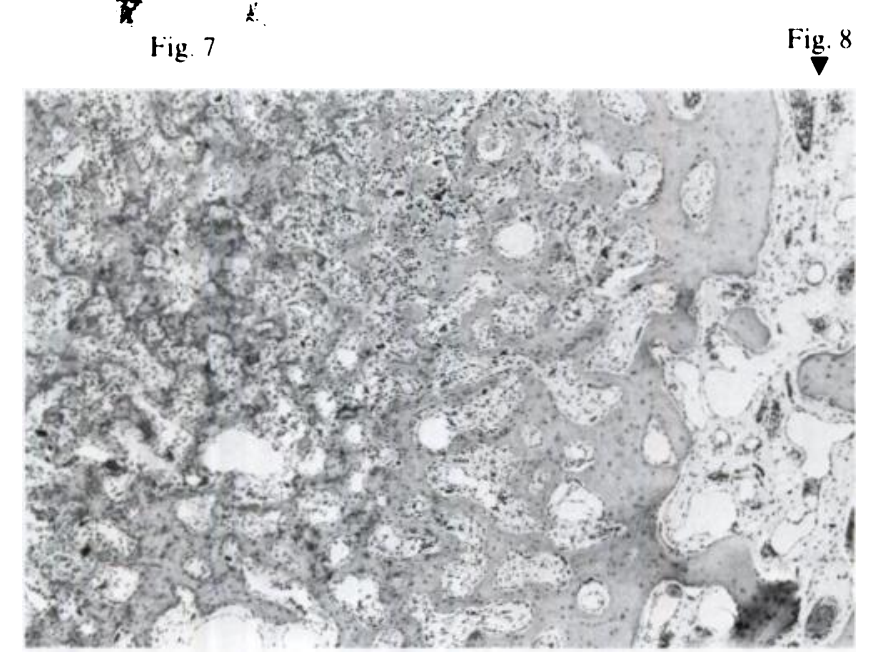

Case 4. A 22-year-old factory worker had pain in the right ankle and hindfoot for one year after a sprain. There was a tender spot on the neck of the talus, and pain was temporarily relieved by local anaesthesia and by salicylates. A bone scan showed diffuse increase in uptake over the whole ankle and mid-foot. Radiographs, tomograms, and an angiogram were normal. At operation on the tender area a small mass of reddish-brown granulation tissue was found beneath the periosteum of the neck of the talus. It was excised, and proved to be an osteoid osteoma. Recovery was uneventful and the paticnt returned to work two months later. shadow reflecting reactive thickening or alteration of neighbouring bone."

The peculiar behaviour of subperiosteal juxtaarticular osteomas was first described by Sherman (1947b), who described a case similar to our Case 2 in which a lesion involved the elbow and caused hypertrophic arthritis. Edeiken, DePalma and Hodes (1966) distinguish three modes of presentation of osteoid osteoma according to the localisation of the nidus in cortical, cancellous or subperiosteal bone. Their description of the subperiosteal lesions includes: "Subperiosteal osteoid osteomas present as round soft-tissue masses 
immediately adjacent to bone ... As a rule underlying bone reveals pressure atrophy or irregular bone resorption ... Instead of invoking reactive bone, they affect neighbouring joints, causing synovitis, effusion and even

Table I. List of reported cases of juxta-articular subperiosteal osteoid osteoma

\begin{tabular}{|c|c|c|c|}
\hline Author & Date & Site & $\begin{array}{l}\text { Original } \\
\text { diagnoses }\end{array}$ \\
\hline Sherman & 1947 & $\begin{array}{l}\text { Elbow } \\
\text { Distal radius }\end{array}$ & Infection \\
\hline Dahlin and Johnson & 1954 & Talus & Arthritis \\
\hline Flaherty e't al. & 1956 & $\begin{array}{l}\text { Talus } \\
\text { Femoral neck }\end{array}$ & \\
\hline Davison & 1956 & Patella & \\
\hline Cuevillas & 1957 & Talus & Arthritis \\
\hline Freiberger et al. & 1959 & $\begin{array}{l}\text { Femoral neck } \\
\text { Distal fibula }\end{array}$ & \\
\hline Guy et al. & 1959 & Femoral neck & \\
\hline Morton and Bartlett & 1966 & Distal ulna & Osteomyelitis \\
\hline $\begin{array}{l}\text { Marcove and Frei- } \\
\text { berger }\end{array}$ & 1966 & $\begin{array}{l}\text { Elbow } \\
\text { Elbow } \\
\text { Elbow }\end{array}$ & $\begin{array}{l}\text { Rheumatoid } \\
\text { arthritis }\end{array}$ \\
\hline Shifrin and Reynolds & 1971 & Elbow & $\begin{array}{l}\text { Entrapment of } \\
\text { ulnar nerve }\end{array}$ \\
\hline Snarr et al. & 1973 & $\begin{array}{l}\text { Femoral neck } \\
\text { Olecranon fossa } \\
\text { Distal humerus } \\
\text { Elbow } \\
\text { Hip }\end{array}$ & $\begin{array}{l}\text { Synovitis } \\
\text { Ewing's tumour }\end{array}$ \\
\hline Corbett et al. & 1974 & $\begin{array}{l}\text { Olecranon } \\
\text { Femoral condyle }\end{array}$ & $\begin{array}{l}\text { Monarticular } \\
\text { arthritis (rheu- } \\
\text { matoid) } \\
\text { Chondromalacia }\end{array}$ \\
\hline Simon and Beller & 1975 & Ankle & \\
\hline Séruzier et al. & 1976 & $\begin{array}{l}\text { Olecranon fossa } \\
\text { Olecranon fossa }\end{array}$ & Arthritis \\
\hline Micheli and Jupiter & 1978 & $\begin{array}{l}\text { Distal femoral epi- } \\
\text { physis }\end{array}$ & Chondromalacia \\
\hline Mitnick et al. & 1979 & Femoral neck & \\
\hline Dinant and Desser & 1981 & $\begin{array}{l}\text { Talus } \\
\text { Femur, greater tro- } \\
\text { chanter }\end{array}$ & $\begin{array}{l}\text { Rheumatoid } \\
\text { arthritis }\end{array}$ \\
\hline Gould & 1981 & Talus & \\
\hline Bleifeld & 1981 & Distal humerus & \\
\hline Cronemeyer et al. & 1981 & Distal humerus & $\begin{array}{l}\text { Osteomyelitis, } \\
\text { rheumatoid arth- } \\
\text { ritis }\end{array}$ \\
\hline Apple and Loughlin & 1981 & Distal tibia & Chronic sprain \\
\hline Shereff et al. & 1983 & $\begin{array}{l}\text { Foot } \\
\text { Foot } \\
\text { Foot } \\
\text { Foot }\end{array}$ & \\
\hline Brabants et al. & 1986 & $\begin{array}{l}\text { Neck of talus } \\
\text { Elbow } \\
\text { Neck of talus } \\
\text { Neck of talus }\end{array}$ & \\
\hline
\end{tabular}

joint deossification suggesting arthritis rather than osteoid osteoma."

The literature on subperiosteal osteoid osteoma is sparse (Table I); only thirty-odd cases have been reported, and in more than half of these the first diagnosis was wrong. The talus and distal humerus seem to be the most common sites. Diagnosis is usually based on the typical pattern of pain, with relief by salicylates, and especially on local tenderness to palpation. Local swelling may be seen, but concomitant joint effusion. muscle atrophy, limitation of movement and local warmth may confuse the diagnosis.

Radiographic changes in bone are absent or very limited. The absence of the bone sclerosis which is typical of cortical osteoid osteoma explains this. Local deossification, slight periosteal new bone formation and joint narrowing may suggest inflammatory arthritis or even osteomyelitis (Sherman 1947a; Dahlin and Johnson 1954; Morton and Bartlett 1966; Mitnick. Braunstein and Genieser 1979; Swee et al. 1979). Bone scans and angiography are also less helpful in subperiosteal osteoma than in the classical cancellous type. Increased uptake of ${ }^{94 m}$ Tc seldom reveals a local hot spot (Swee et al. 1979), but is usually diffuse and results from reactive hyperaemia and associated synovitis (Bleifeld 1981; Mitnick 't al. 1979; Swee et al. 1979; Shereff. Cullivan and Johnson 1983). CT scans of the elbow and the hindfoot are said to be difficult to interpret because of the anatomical complexity of these regions (Gould 1981), although in our Case 2 the nidus was clearly shown.

Angiograms are helpful in classic osteoid osteoma: they show small curled vessels in the early arterial phase and a blush in the late arterial phase, which is prolonged into the venous phase (Swee et al. 1979). Angiograms were helpful in only one of our cases.

The pathogenesis of the synovitis seen in juxtaarticular osteoid osteoma is not clear. The synovium is macroscopically thickened, brittle and oedematous; microscopically the synovitis is non-specific (Sherman 1947a; Cuevillas 1957; Guy et al. 1959; Morton and Bartlett 1966; Shifrin and Reynolds 1971; Bleifeld 1981; Dinant and Desser 1981). Whether this synovitis is of mechanical origin or due to substances from the tumour remains uncertain (Snarr, Abell and Martel 1973; Séruzier et al. 1976; Dinant and Desser 1981). The local periosteal reaction sometimes seen at a distance from a juxta-articular osteoid osteoma is probably, as in rheumatoid arthritis, secondary to the synovitis (Bleifeld 1981).

Treatment of juxta-articular osteoid osteoma is simple; removal of the nidus will solve the problem. Indeed "persistence of typical symptoms after surgery may mean that the nidus was missed" (Sim et al. 1975). Pre-operative localisation of the nidus can be ideally done with a probe bone scanner, but this costly equipment is hardly necessary for the superficial lesions we have described. After excision of the nidus the synovial 
inflammation settles and a normal range of joint movement eventually returns (Sherman 1947a; Shifrin and Reynolds 1971).

Conclusion. Juxta-articular subperiosteal osteoid osteoma is a small, rare, benign bone tumour. It provides a diagnostic challenge because of the absence of specific features on radiography and other diagnostic investigations. CT scanning is probably the best supplement to clinical examination, but diagnosis is often delayed. Marking the area of maximal tenderness before operation helps to localise the nidus and facilitates its excision.

\section{REFERENCES}

Apple DF Jr, Loughlin EC Jr. Osteoid osteoma of the ankle in an athlete. Am J Sports Med 1981:9(4):2545.

Bleifeld C. Osteoid osteoma: articular communication and minimal pain. NY State J Med 1981:81:13712.

Corbett JM, Wilde AH, McCormack LJ, Evarts CM. Intra-articular osteoid osteoma: a diagnostic problem. Clin Orthop 1974:98: 22530.

Cronemeyer RL, Kirchmer NA, De Smet AA, Neff JR. Intra-articular osteoid osteoma of the humerus simulating synovitis of the elbow: a case report. J Bone Joint Surg $[A m]$ 1981:63 A:1172 4.

Cuevillas AR. Osteoma osteoide yuxtaarticular. Prensa Mèd Argent 1957:44:33857.

Dahlin DC, Johnson EW. Giant osteoid osteoma. J Bone Joint Surg $[\mathrm{Am}]$ 1954:36-A:559-72.

Davison WR. Osteoid osteoma: report of atypical cases. Clin Orthop 1956:7:113 23.

Dinant HJ, Desser EJ. Osteoid osteoom: een ongewone oorzaak van chronische monarthritis bij twee jeugdige patienten. Ned Tijdschr Gene'sk d 1981:125(27): 1080 3. [Eng. Abstr.]

Edeiken J, DePalma AF, Hodes PJ. Osteoid osteoma: roentgenographic emphasis. Clin Orthop 1966:49:201 6.

Flaherty RA, Pugh DG, Dockerty MB. Osteoid osteoma. AJR 1956:76: 104151
Freiberger RH, Loitman BS, Helpern M, Thompson TC. Osteoid osteoma: a report on 80 cases. $A J R$ 1959;82:194 205.

Gould N. Articular osteoid osteoma of the talus: a case report. Foot Ankle 1981:1:284 5.

Guy R, Fortier M, Boivin JM, Raymond O, Bourgeois J. Observation d'un cas d'ostéome ostéöde avec pathologie articulaire. Union Med Can 1959;88:816 24.

Jaffe HL. "Osteoid osteoma": a benign osteoblastic tumor composed of osteoid and atypical bone. Arch Surg 1935:31:709 28.

Jaffe HL. Osteoid-osteoma. Tumors and tumorous conditions of the hone and joints. London: H Kimpton. 1958:92 106.

Marcove RC, Freiberger RH. Osteoid osteoma of the elbow-a diagnostic problem: report of four cases. J Bone Joint Surg $[A m]$ 1966; $48 \mathrm{~A}: 1185-90$.

Micheli LJ, Jupiter J. Osteoid osteoma as a cause of knee pain in the young athlete: a case study. Am J Sports Med 1978:6(4): 199203.

Mitnick JS, Braunstein P, Genieser NB. Osteoid osteoma of the hip: unusual isotopic appearance. $A J R$ 1979:133:322 3.

Morton KS, Bartlett LH. Benign osteoblastic change resembling osteoid osteoma: three cases with unusual radiological features. J Bone Joint Surg $[B r]$ 1966;48 B:478 84 .

Séruzier E, Simonin JL, Ducastelle C, et al. Ostéome ostéoïde avec synovite a propos de deux observations. Re' Rhum Mal Osteoartic 1976:43(79):521 6.

Shereff MJ, Cullivan WT, Johnson KA. Osteoid osteoma of the foot. $J$ Bone Joint Surg [Am] 1983:65-A:638-41.

Sherman MS. Osteoid osteoma associated with changes in adjacent joint: report of two cases. J Bone Joint Surg 1947a:29:483 90.

Sherman MS. Osteoid osteoma: review of the literature and report of thirty cases. J Bone Joint Surg 1947b;29:918 30.

Shifrin LZ, Reynolds WA. Intra-articular osteoid osteoma of the elbow: a case report. Clin Orthop 1971;81:1269.

Sim FH, Dahlin DC, Beabout JW. Osteoid osteoma: diagnostic problems. J Bone Joint Surg $[\mathrm{Am}]$ 1975:57- A:154 9.

Simon WH, Beller ML. Intracapsular epiphyseal osteoid osteoma of the ankle joint: a case report. Clin Orthop 1975; 108:200 3.

Snarr JW, Abell MR, Martel W. Lymphofollicular synovitis with osteoid osteoma. Radiology 1973;106:557 60.

Swee RG, McLeod RA, Beabout JW. Osteoid osteoma: detection diagnosis and localization. Radiology 1979:130:117 23.

Wiener SN, Kirschenbaum D. Osteoid osteoma presenting as regional osteoporosis. Clin Nucl Med 1980:5(2):68 9. 